\title{
WHY SOME SME'S IN THE CZECH REPUBLIC ADOPT TELEWORK AND OTHERS NOT?
}

Jaroslav Vrchota, Zuzana Frantíková, Miroslava Vlčková ${ }^{1}$

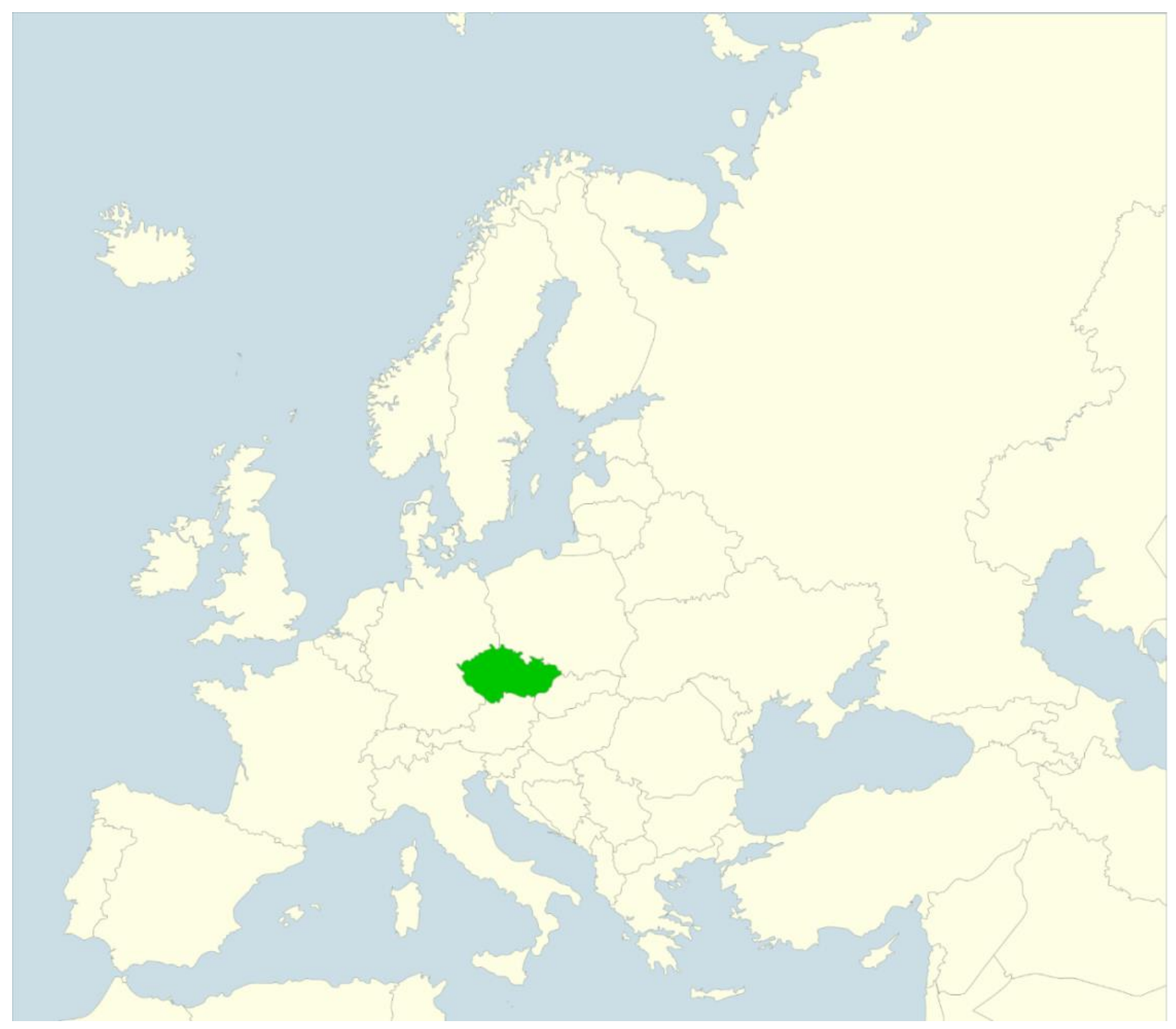

\footnotetext{
1 Ing. Jaroslav Vrchota, Ph.D., vrchota@ef.jcu.cz, ORCID: 0000-0002-8363-3131; Mgr. et Mgr. Zuzana Frantíková, zfrantikova@ef.jcu.cz, ORCID: 0000-0003-4376-6092; Ing. Miroslava Vlčková, PhD., mvlckova02@ef.jcu.cz, ORCID: 0000-0002-6935-3037. University of South Bohemia in Česke Budějovice, Studentska 13, 37005 Česke Budějovice, Czech Republic
} 


\begin{abstract}
The paper examines the SME's in the Czech Republic from the perspective what makes them to adopt telework using the data from the research made in 2017. The research includes 1018 SME' s. The purpose of the study was to try to find out alignment between telework and some organizational constraints. We hypothesized that employer adoption of telework would depend on the size of the firm, the duration of telework adoption, foreign owner, IT level, and on the implementation of project management. Our empirical evidence showed that telework correlated with the foreign owner participation and the duration of the adoption of telework, with the IT level and with the adoption of project management. It does not correlate with the size of the enterprise and the duration of the adoption of telework.
\end{abstract}

Key words: telework, SME, IT technology, project management

\begin{abstract}
Abstrakt: Příspěvek se zabývá teleworkem u malých a středních podniků (MSP) v České republice s využitím údajů $z$ výzkumu provedeného $v$ roce 2017 . Výzkum zahrnuje 1018 MSP. Cílem studie bylo pokusit se zjistit sladění teleworkingu a některých organizačních omezení. Předpokladem bylo, že zaměstnavatelé využívají telework v záviseli na velikosti firmy, době zavedení teleworku, zahraničním majiteli, IT úrovni a na využívání prvků projektového řízení. Naše empirické důkazy ukázaly, že práce na dálku korelovala $s$ účastí zahraničních vlastníků, s úrovní IT a s využíváním projektového rrízení. Naopak teleworking nesouvisí s velikostí podniku a délkou zavedení teleworku.
\end{abstract}

Klíčová slova: Teleworking, Homeworking, MSP, IT technologie, projektový management

\title{
1. Introduction
}

For many people, rural areas are homes - a place to live, work and raise families. One way to achieve this state is to ensure synergism between locality, family, and work. If we omit work in local businesses, telework and occasional commuting represents an ideal compromise. This paper discusses SMEs' access to telework and the factors affecting business owners when they implement telework. From a management perspective, these factors are: business size, foreign business owner, IT usage level, or project management features. Finally, it is up to business owners who decide whether or not to support this form of work.

In the Czech Republic, telework is regulated in Section 317 of Act No. 262/2006 Sb., the Labor Code. It is defined as the regime of work of an employee who does not work the employer's place of work but under the agreed conditions and who performs a negotiated job during the working hours he/she plans. Sections regarding working hours, overtime, compensation of wages, spare time off in case of overtime and compensation of wages in case of some personal obstacles on the employee's side cannot be applied in case of telework. On the other hand, employers should compensate the costs paid by the distant/home employees, however, this is regulated implicitly and that's why most employers do not keep the regulation and do not compensate the costs employee's pay by doing their work from home. Therefore, the new proposal of the amendment of Labor Code counts with the implementation of new regulation consisting of the specification of the employers' duty to compensate the costs arising on employee's side (Bělina, 2015).

Unlike the legal regulation in other countries, in the Czech Republic, the regulation of telework does not emphasize the usage of IT technology and the regularity of using the telework but the freedom regarding the working hours on the employee' s side, which is not often understood well by the participants. However, as shown in our study, IT level plays a key role in the adoption of telework (Boell, S. K., Cecez-Kecmanovic, D., \& Campbell, J., 2016). Unfortunately, from the survey, it resulted that the Czech SME's mostly has a poor IT level whereas $63 \%$ of SME's that adopted telework has been using it for six to ten years. 
In accordance with the European Trade Union Confederation, telework is defined as a form of organizing and/or performing work, using information technology, where work, which could also be performed at the employers' premises, is carried out away from those premises on a regular basis (Implementation, 2006).

\section{Theoretical background}

In the Czech Republic, many articles have been written on this theme. However, it seems that it has been topical ten years ago and since then nobody has examined this theme again despite the fact that with the low rate of unemployment in the Czech Republic, it can be topical again as shown in our study because employers often stated that they adopted telework due to the need of an employee specialist living far away from the workplace. The articles (Kyzlinková, R., \& Svobodová, K., 2007; Křížková, A., \& Vohlídalová, M.,2009; Temelová, J., Novák, J., Pospíšilová, L., \& Dvořáková, N., 2011; Maříková, H., 2008; Kř́žková, A., 2007) focused mainly on the gender and family problems in connection with telework and they do not study the telework situation in the Czech Republic in such a large scale and from the employer organizational perspective.

Telework as a concept was first introduced as telecommuting by Jack Nilles; he coined it while he was stuck in a traffic jam in Los Angeles (Kurland \& Bailey, 1999). In the 1980's, in the USA, there was a big emphasis on cutting costs from the employer's side and on the ecological problems because California struggled with the air pollution caused by the immense usage of cars (Kurland \& Bailey, 1999; Handy and Mokhtarian, 1995; Mannering and Mokhtarian, 1995). The adoption of telework in the USA led to the reduction of the expense of maintaining office space (Kurland \& Bailey, 1999). Later, the increase of telework in the USA was caused allegedly due to the tragedy that occurred on September 11, 2001 and safety measurements were implemented in the country (Potter, 2003). Unlike the Industrial Age, where big industrial centres were built up, telework represents an opposite tendency (Potter, 2003). Among other factors stimulating the growth of telework were the boom of IT technology and the accrual of dual-earner households and due to this fact, the need for work-life balance (Potter, 2003). Unlike the Czech Republic, where there is a big tradition of dual-earner families - this started already in the fifty's with the origin of communism regime. The USA includes four types of telework: home-based telecommuting, satellite offices, neighbourhood work centre and mobile workers, (Potter, 2003; Kurland \& Bailey, 1999). However, the reasons to adopt telework has changed recently. Organizations have begun to view telecommuting as a tool to attract and retain top personnel in fields with short labour supplies. The paper examines the organizational readiness to implement telework (Steil \& Barcia, 2001). We asked whether it is the foreign owner who inspired the SME to adopt telework.

Although telework can be defined in many ways, we are interested in all situations where an employee works from home at least sometimes. The proportion of teleworkers in the Czech Republic has been estimated to be in the range of $2.92 \%$ among all workers. However, these estimates are typically based on cases where employees regularly or always use telework and could exclude cases where employees telework on an occasional or irregular basis. For employers, implementing telework potentially generates cost savings by adapting available labour levels to fluctuations in demand for their services, and by reducing or restraining the need for real estate, office space, supplies (Peters et al., 2010; Verbeke et al., 2008) and other overheads (Morgan, 2004). However, these cost savings on the employer's side cause an increase of cost on the employee's side (Baruch, 2000). Several researchers have found a small but robust empirical relationship between the use of specific work practices and firm level outcomes such as profitability and productivity (e.g., Delery and Doty, 1996; Gerhart et al., 2000; Huselid, 1995; Jiang et al., 2012; Wright and McMahan, 1992). One reason why strategically chosen organizational practices can lead to improved firm performance is that the human capital of a workforce can be unleashed and fully utilized (see Wright and McMahan, 2011).

'The category of micro, small and medium-sized enterprises (SMEs) is made up of enterprises which employ fewer than 250 persons and which have an annual turnover not exceeding 50 million euro, and/or an annual balance sheet total not exceeding 43 million euro'. (SME 
definition, 2005). In the Czech Republic, the share of SMEs in the total number of active enterprises in 2014 was $99.84 \%$. The share of employees of small and medium enterprises in the total number of employees in the business sector in the Czech Republic in 2014 amounted to $59.39 \%$, which means that SME' s employ most employers on the Czech employment market.

The UK Association of Project Management (APM) have produced a UK Body of Knowledge UK (BoK) which also provides a definition for project management as: the planning, organisation, monitoring and control of all aspects of a project and the motivation of all involved to achieve the project objectives safely and within agreed time, cost and performance criteria. The project manager is the single point of responsibility for achieving this. We are convinced that the PMJ implementation correlates with the use of telework despite the size of SME or the foreign ownership. It may be the project management that allows SME to adapt easily to telework.

Many papers focus on the influence of telework on the effectivity, productivity, satisfaction, stress, and leisure time of the employee or on similar areas. The biggest advantage of this model of work is the elimination of time dedicated to commuting (e.g. Abdel-Wahab, 2007; Haddad, Lyons \& Chatterjee, 2009). The higher satisfaction with work and the sensation of autonomy are ones of typical features of teleworking (Aline D. et al., 2012; Baltina \& Vitola, 2014; Brenke, 2016; Redman, Snape, \& Ashurst, 2009). The European survey has shown that telework boosts productivity and the possibility to relax during the working hours, but it brings longer working hours, higher need to work overtime and higher level of stress (Eurofound and the International Labour Office, 2017; Martin \& MacDonnell, 2012). On the other hand, other surveys show that the level of stress is decreased by the telework (Ravi S. \& David A., 2007; Redman et al., 2009). However, there are opinions that the deletion of differences between work time and leisure time may lead to serious health problems (Peters \& van der Lippe, 2007).

One of the most interesting problems in this area is the relation between work from home and the home to work distance. The studies in these countries do not bring a clear answer if the primary hypothesis that telework relates to the equal area distribution of population is confirmed. The research performed in Ireland, South Korea, Netherlands, Canada or Finland outline that it could be like this (Caulfield, 2015; Helminen \& Ristimäki, 2007; Muhammad, Ottens, \& Jong, 2008; Saim Muhammad et al., 2007; Seung-Nam Kim, 2016; Tayyaran \& Khan, 2007). On the other hand in Greece, Lithuania or in other Dutch research, these tendencies do not show or confirm that, rather the contrary (Amalia Polydoropoulou \& Athena Tsirimpa, 2012; Armitage, 2000; de Graaff \& Rietveld, 2007; Vilhelmson \& Thulin, 2016).

\section{Methodology}

\subsection{Aim}

The aim of the paper is to analyze the factors influencing telework in small and medium-sized enterprises in the Czech Republic. The partial objectives are to determine to what extent the adoption of telework is influenced by the size of the company, the foreign owner, the IT level in the company, or the use of project management influence. These partial objectives are subsequently verified by established hypotheses using the statistical tests described below.

The data for the survey was collected by the means of an electronic questionnaire in 2017, which was distributed electronically to SMEs, out of the total number of 53,365 small and medium-sized companies contacted, data from 1076 were obtained, where, after checking the obtained data, the sample was cleaned up to 1018 SMEs. SMEs were then divided according to the EU methodology (SME definition, 2005) to Micro (213), Small (493) and Medium (312).

\subsection{Statistical methods}

In cases where dependencies and relationships were identified among data, the test data were categorized into several categories, the test data were modified using a Pivot table for a further comparison of them. Contingent tables were made up of two nominal quantities $X, Y$. Let $X$ get the variants from $x_{[1]}, \ldots \ldots \ldots . . . . ., x_{[r]}$ and $Y$ get the variants from $y_{[1]} \ldots \ldots \ldots \ldots . . . . ., y_{[s]}$. We denote $\pi j k=P\left(X=x_{[j]} \wedge Y=y_{[k]}\right)$, the simultaneous probability of the variant pair $\left(x_{[j]} y_{[k]}\right), \pi_{j}=P\left(X=x_{[j]}\right)$ the marginal probability of variance $y_{[k]}$ (Freund, 2010; Freeman, 2017). Then, a two-dimensional 
random selection of the range $\mathbf{n}$ from the layout that is directed by the two-dimensional discrete random vector $(X, Y)$ was obtained. The observed absolute simultaneous frequencies $n_{j k}$ of the two variants $\left(\mathrm{x}_{[j]} \mathrm{y}_{[\mathrm{k}]}\right)$ are arranged in the pivot table (Devore, 2015; Budíková, 2010).

The frequency is determined from the relation where $n_{j}=n_{j 1}+\ldots+n_{j s}$ is the marginal absolute frequency of the variant $x_{[j]}, n_{k}=n_{1 k}+\ldots+n_{r k}$ is the marginal absolute frequency of the variant $y_{[k]}$. Furthermore, we estimated the simultaneous probability by using the simultaneous relative frequency $p_{j k}=\frac{n_{j k}}{n}$, the marginal probability $\pi j$ and $\pi k$ are estimated by marginal relative frequencies $p j=\frac{n_{j k}}{n}$ and $p . k=\frac{n_{k}}{n}$ (Freeman, 2017). We tested the zero hypothesis $H 0: X, Y$ are stochastically independent random variables against the alternative $\mathrm{H} 1: \mathrm{X}, \mathrm{Y}$ are not stochastically independent random variables. The test is based on the comparison of the observed frequencies $\mathrm{n}_{\mathrm{jk}}$ and the so called theoretical frequencies $\frac{\mathrm{n}_{\mathrm{j}} \times \mathrm{n}_{\mathrm{k}}}{\mathrm{n}} \mathrm{o}$ the pair of variants $\left(\mathrm{x}_{[\mathrm{j}]}, \mathrm{y}_{[\mathrm{k}]}\right)$, which should be very similar in the case of the zero hypothesis (Freund, 2010; Meloun, 2012).

The statistics tested have the shape: $\mathrm{K}=\sum_{\mathrm{j}=1}^{\mathrm{r}} \cdot \sum_{\mathrm{k}=1}^{\mathrm{s}} \frac{\left(\mathrm{n}_{\mathrm{jk}}-\frac{\mathrm{n}_{\mathrm{j} \times \mathrm{n}_{\mathrm{k}}}}{n}\right)^{2}}{\frac{\mathrm{n}_{\mathrm{j} \times \mathrm{n}_{\mathrm{k}}}}{\mathrm{n}}}$ (Spellman, 2014)

For the test, the conditions of good approximation ( $80 \%$ gain the value $\geq 5$ and the rest $20 \%$ they do not drop under 2) are satisfied, then the statistics $K$ are asymptotically controlled by the distribution of $X^{2}((r-1)(s-1))$. The critical field of values $\left.W=<X^{2}{ }_{1-\alpha}((r-1)(s-1)), \infty\right)$. Therefore, the hypothesis of the independence of the variables $X, Y$ is rejected on the asymptotic level of significance $\alpha$ when the tested $\mathrm{K}$ statistics is implemented in the critical field W (Freund, 2010). In the case of the rejection of the zero hypothesis, the strength of the dependence of the measured quantities of the nominal type is determined by the Cramer's coefficient:

$\mathrm{V}=\sqrt{\frac{\mathrm{K}}{\mathrm{n}(\mathrm{m}-1)}}($ Walker, 2010)

Where $n$ denotes the range and $m=\min \{r, s\}$. This coefficient assumes the values between 0 and 1 . The closer it is to 1 , the closer the dependence between $X$ and $Y$ is, the closer it is to 0 , the more independent the dependency is.

The meaning of values (Budíková, 2010):

0 to 0.1 - insignificant dependence

0.1 to 0.3 - weak dependence

0.3 to 0.7 - middle dependence

0.7 to 1 - strong dependence

Where we compare only two groups of variables, most often the YES group and the NO group, with variable values, a zero hypothesis will always be placed in the calculation that the group YES and the NO group match on the basis of the analyzed data and the alternative hypothesis that the YES data group reaches higher level of telework than the NO group. The data were tested using a Wilcoxon two-choice test (Freund 2010, Freeman, 2017) and its asymmetric variants. This is a non-parametric two-sampling test, which is most often used when the condition of normality of data is not met. Since a slight disturbance of normality in samples larger than 30 does not have a significant impact on test results (Freeman 2017; Devore, 2015). $X_{1}, \ldots, X_{n}$, and $Y_{1}, \ldots$, $Y_{m}$ be two random selections from two continuous distributions, whose distribution functions can differ only by shifting. $\mathrm{x}_{0,50}$ and $\mathrm{y}_{0,50}$ are marked as the median of the first and second layouts.

We always test the hypothesis that the distribution functions of the two distributions are identical, in other words, that the medians equate. Against the alternative, the first of the medians $x_{0,50}$ is larger than the second one mentioned (Budíková 2010, Freund 2010).

$\mathrm{H}_{0}=\mathrm{x}_{0,50}-\mathrm{y}_{0,50}=0$ proti $\mathrm{H}_{\mathrm{A}}=\mathrm{x}_{0,50}>\mathrm{y}_{0,50}$ (Walker, 2010)

In the first stage, all $(n+m)$ of values $X_{1}, \ldots, X_{n}$ a $Y_{1}, \ldots, Y_{m}$ are arranged in ascending order by size. Since the whole test process is done electronically using the Statistics ver. 10, this step in the work is not recorded because it is just a lapidary operation. In addition, the summaries of 
the order of values $X_{1}, \ldots, X_{n}$ and it is identified as $T_{1}$. Sum of the values in the group NO $Y_{1}, \ldots$, $Y_{m}$ will be marked $T_{2}$. The next step is the calculation of the tested statistics for U1 and U2, while U1 + U2 = mn (Budíková 2010; Spellman 2014).

$\mathrm{U}_{1}=\mathrm{mn} \frac{\mathrm{n}(\mathrm{n}+1)}{2}-\mathrm{T}_{1}, \mathrm{U}_{2}=\mathrm{mn} \frac{\mathrm{m}(\mathrm{m}+1)}{2}-\mathrm{T}_{2}$ (Walker, 2010)

If the statistics $\min \left\{U_{-}(1,) U_{-} 2\right\} \geq$ tableted the critical value for the selected ranges of both selections and the chosen significance level, then the zero hypothesis about the identity of the compared groups is rejected at the significance level $\alpha=0,05$. Since for both samples, in all tested cases, $n, m$ are greater than 30, an asymptotic variant of the Wilcoxon test (Mann-Whitney test) is used, which is used for $n$ and $m$ bigger than thirty. Where $U^{\prime} 1=\min \left\{U_{1}, U_{2}\right\}$ (Walker 2010, Meloun 2012).

$\mathrm{U}_{0} \frac{\mathrm{U}_{1}^{\prime}-\frac{\mathrm{mn}}{2}}{\sqrt{\frac{\mathrm{mn}(\mathrm{m}+\mathrm{n}+1)}{12}}}($ Walker, 2010)

The critical field of values for the right-hand alternative $W=\left\langle k 2, n>\right.$ the non-negative values $k_{1}$ and $\mathrm{k}_{2}$ are exactly given in the literature. $\mathrm{HO}$ is rejected at the level of significance $\alpha$ if $\mathrm{UO} \in \mathrm{W}$ (Freund 2010, Freeman 2017).

\section{Results}

605 SMEs of the total number of companies has been using telework for an average period of 7 years. Both the modus and the median in this group equates 5 years, with a frequency of 126 . The dispersion value is 28.1 , where the minimum value is 1 and the maximum is 30 years. The data are distributed based on the lower quartile with a value of 3 years and an upper quartile with a value of 10 years. Generally, there are 413 businesses that do not use telework.

\subsection{TW and size of the company}

First, the data was compared based on the use of telework by defined groups (1-5 years, 610 years, 11-20 years, over 21 years) and SME size (Micro, Small, Medium sized enterprises). As shown in the table below, all types of companies are represented: Micro (118), Small (303), Medium (184). The table does not list companies that do not use telework, i.e., $46 \%$ of Micro, $39 \%$ of Small enterprises, and $41 \%$ of Medium enterprises - these data were not used due to subsequent percentage distortion. Most companies have been using TW for only a short period of time from 1 to 5 years, which represents $57 \%$ of the total. In the case of all companies, it is evident that telework has been used less and less within the years, but this will be due to their growth over the years and thus the transition to another category of SMEs.

Simultaneously, it was tested whether there was a relationship between TW adoption duration and the size of the enterprise, therefore a hypothetical hypothesis $\mathrm{H}_{0}$ was stated: the TW adoption duration and the size of the enterprise are independent, $\mathrm{Ha}$ : non $\mathrm{H}_{0}$. Hypotheses were tested using the $\mathrm{X}^{2}$ independence test statistic with one degree of freedom at the chosen significance level $\alpha=0.05$. Due to good approximation conditions, Pearson's chí- kv test was used, where $\chi^{2}=6.2257, p$-value $=0.6220$. For this reason, it was not possible to reject the zero hypothesis and hence it could even be henceforth claimed that TW duration adoption and company size are independent. 
Tab 1. Pivot table based on TW duration and SME size. Source: created by authors

\begin{tabular}{|c|c|c|c|c|c|c|}
\hline & Company size & TW 21-more & TW 11-20 & TW 6-10 & TW 1-5 & $\begin{array}{l}\text { Rádky } \\
\text { součet }\end{array}$ \\
\hline Frequency & \multirow{4}{*}{ Micro } & 3 & 17 & 38 & 60 & 118 \\
\hline Columns frequency & & $2.27 \%$ & $20.73 \%$ & $22.49 \%$ & $17.49 \%$ & \\
\hline Lines frequency & & $2.54 \%$ & $14.41 \%$ & $32.20 \%$ & $50.85 \%$ & \\
\hline Total frequency & & $0.50 \%$ & $2.81 \%$ & $6.28 \%$ & $9.92 \%$ & $19.50 \%$ \\
\hline frequency & \multirow[t]{4}{*}{ Small } & 4 & 47 & 77 & 175 & 303 \\
\hline Columns frequency & & $36.36 \%$ & $57.32 \%$ & $45.56 \%$ & $51.02 \%$ & \\
\hline Lines frequency & & $1.32 \%$ & $15.51 \%$ & $25.41 \%$ & $57.76 \%$ & \\
\hline Total frequency & & $0.66 \%$ & $7.77 \%$ & $12.73 \%$ & $28.93 \%$ & $50.08 \%$ \\
\hline frequency & \multirow[t]{4}{*}{ Medium } & 4 & 18 & 54 & 108 & 184 \\
\hline Columns frequency & & $36.36 \%$ & $21.95 \%$ & $31.95 \%$ & $31.49 \%$ & \\
\hline Lines frequency & & $2.17 \%$ & $9.78 \%$ & $29.35 \%$ & $58.70 \%$ & \\
\hline Total frequency & & $0,6 \%$ & $2.98 \%$ & $8.93 \%$ & $17.85 \%$ & $30.41 \%$ \\
\hline frequency & \multirow[t]{2}{*}{ Total } & 11 & 82 & 169 & 343 & 605 \\
\hline Total frequency & & $1.82 \%$ & $13.55 \%$ & $27.93 \%$ & $56.69 \%$ & $100.00 \%$ \\
\hline
\end{tabular}

\subsection{TW and foreign owner}

Subsequently, there was a hypothesis stated by two-volume Wilcoxon's test (Mann-Whitney $\mathrm{U}$ test) where $\mathrm{X}$ represent companies without a foreign owner against the companies with a foreign owner. $\mathrm{H}_{0}=\mathrm{x}_{0,50}-\mathrm{y}_{0,50}=0$ against $\mathrm{HA}=\mathrm{y}_{0,50}>\mathrm{x}_{0,50}$. To clarify the hypothesis, the most important data are summarized in the table below, where all sizes of companies were tested. In the total line, there is a rejection of the zero hypothesis where the $p$-value is very close to zero. The alternative hypothesis was confirmed, and hence, we can claim that foreign-owned companies, has been using TW longer than companies without foreign ownership. From the distribution of data, it is interesting that companies with no foreign participation (806 in total) have higher maximum values up to 30 years, compared to foreign enterprises (212), where the maximum is 25 years. The graph below shows the individual frequencies even with the average values. At the same time, foreign-owned companies use TW more $-70 \%$ of foreignowned companies use TW compared to $58 \%$ companies without a foreign owner.

Tab 2. Mann-Whitney's U test aimed at the use of TW in companies with/without a foreign owner. Source: created by authors

\begin{tabular}{|l|c|c|c|c|c|c|c|}
\hline & $\begin{array}{c}\text { Without } \\
\text { foreign owner }\end{array}$ & $\begin{array}{c}\text { With } \\
\text { foreign owner }\end{array}$ & $\mathrm{U}$ & $\mathrm{Z}$ & $\mathrm{p}$-value & $\begin{array}{c}\text { Number of } \\
\text { the valid } \\
\text { No }\end{array}$ & $\begin{array}{c}\text { Number of } \\
\text { the valid } \\
\text { Yes }\end{array}$ \\
\hline total & 393527.5 & 125143.5 & 68306.50 & 4.49676 & 0.000007 & 806 & 212 \\
\hline Micro sized & 19525.00 & 3266.000 & 1947.000 & 1.64200 & 0.100591 & 187 & 26 \\
\hline Small size & 97847.00 & 23924.00 & 13181.00 & 3.11535 & 0.001837 & 411 & 82 \\
\hline $\begin{array}{l}\text { Medium } \\
\text { sized }\end{array}$ & 30286.50 & 18541.50 & 8550.500 & 3.01535 & 0.002567 & 208 & 104 \\
\hline
\end{tabular}

Similar results were obtained for Small and Medium sized enterprises where both $p$-values $(0.0018$ and 0.0026$)$ were smaller than the selected alpha. At the same time, these cases confirmed the alternative hypothesis that businesses with a foreign owner use more TW, as illustrated graphically below. The zero hypothesis was not rejected in the case of Micro enterprises where the value of the tested $p$-value statistics is 0.1006 . 


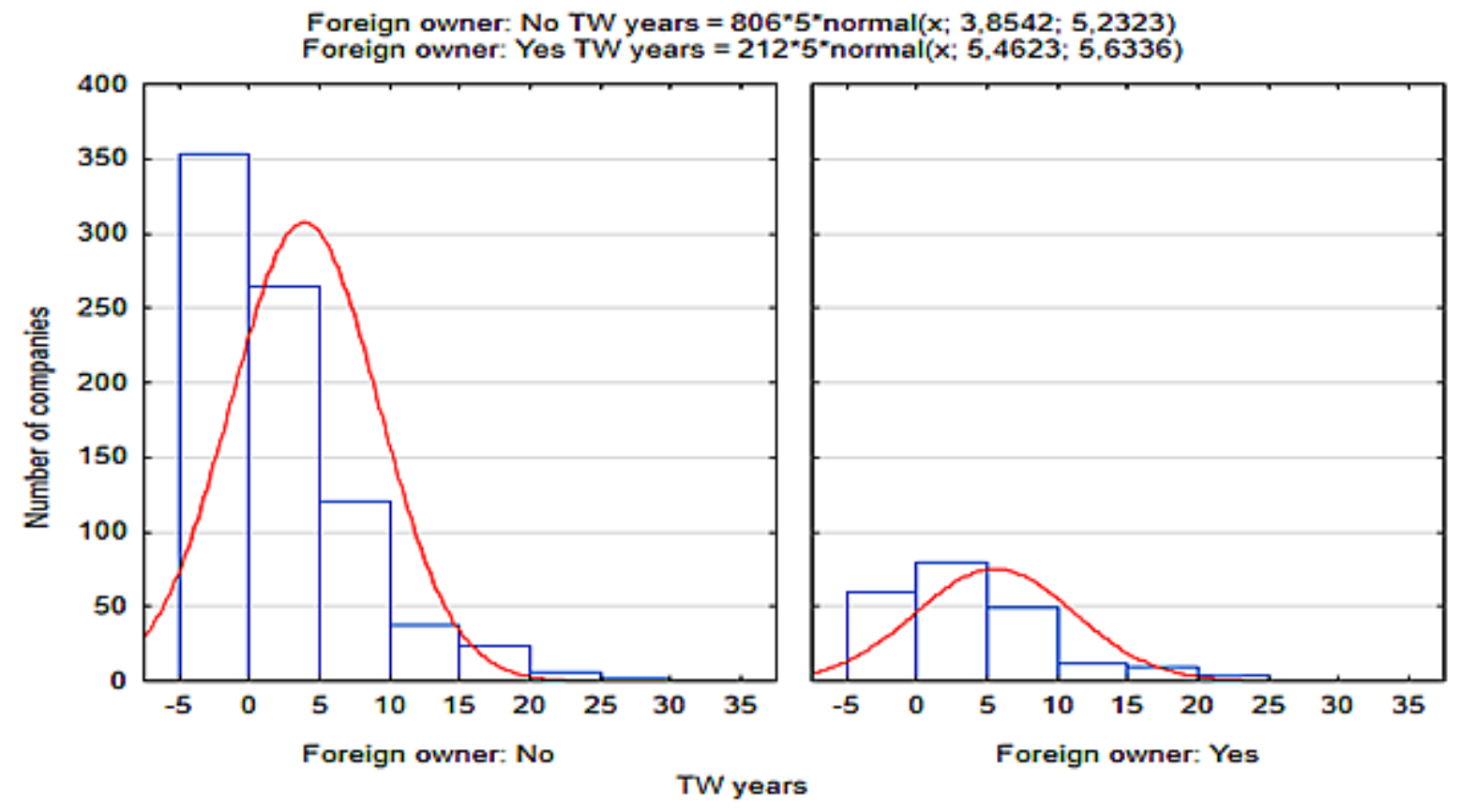

Fig 1. TW data distribution for companies with foreign and non-foreign owner. Source: created by authors

In the left part of the graph there are enterprises without a foreign owner, where the peak of the curve showing the time of use of TW is 3.9 compared to the right part featuring companies with foreign equity, where the peak of the curve is 5.5 .

\subsection{TW and IT}

The next hypothesis was related to the adoption of TW and the dependence/correlation on IT level in Small and Medium-sized firms. For the data, the level of utilization of information technologies potentially supporting TW was used. The level was determined on a scale from 0 to 6 , where 0 represents a very low level and 6 a very high level. The scales were classified based on questions related to (cloud services, ERP systems, online voice and video chat, chat, document sharing, synchronization of calendars and tasks, or specialized software). Out of 1018 companies, 279 have zero level, which represents $27 \%$ of the total, $21 \%$ of all companies have level one and two, while the last sixth level was reached only just by $1 \%$ of SMEs.

What is interesting is the distribution of data from the point of view of the duration of TW adoption and the IT level. For example, from the enterprises reaching the IT level 4, non-TW companies represent at least $8 \%$, compared to $52 \%$ of enterprises using TW from 1 to 5 years. The results of SMEs with IT level 0 turned out similar. TW is not used by $82 \%$ of Small and Medium sized enterprises, compared to only $10 \%$ of enterprises using it from 1 to 5 years. Surprisingly, the IT level 6 is used by $63 \%$ of companies for $6-10$ years. From the point of view of the duration of TW adoption, the groups of enterprises with IT level 2-4 are very similar. The most represented enterprises are the enterprises with TW from 1 to 5 years followed by enterprises with TW from 6 to 10 years, where their representation within the groups is between 20-28\%. Similar representation about $11 \%$ of the TW companies is in the category from 11 to 20 years. Most of the sample is represented by IT level 0 and non-TW with $22.4 \%$, while non-TW companies with IT level 0 are $55 \%$ and $22 \%$ of them with IT level 1 . From the point of view of the data characteristics described above, the hypothesis on the independence of the IT level and the duration of TW adoption has been tested. 
Tab 3. Mann-Whitney U test focused on the use of IT in companies with or without TW. Source: created by authors

\begin{tabular}{|l|c|c|c|c|c|c|c|}
\hline & TW Yes & TW No & $U$ & $Z$ & $p$-value & $\begin{array}{c}\text { Number of } \\
\text { the valid } \\
\text { TW Yes }\end{array}$ & $\begin{array}{c}\text { Number of } \\
\text { the valid } \\
\text { TW No }\end{array}$ \\
\hline total & 384984.5 & 133686.5 & 48195.50 & 16.65915 & 0.000000 & 605 & 413 \\
\hline $\begin{array}{l}\text { Foreign } \\
\text { owner YES }\end{array}$ & 18895.50 & 3682.500 & 1852.500 & 6.728088 & 0.000000 & 152 & 60 \\
\hline $\begin{array}{l}\text { Foreign } \\
\text { owner NO }\end{array}$ & 231177.0 & 94044.00 & 31563.00 & 14.75645 & 0.000000 & 453 & 353 \\
\hline Micro sized & 16465.50 & 6325.500 & 1765.500 & 8.586161 & 0.000000 & 118 & 95 \\
\hline $\begin{array}{l}\text { Small } \\
\text { Sized }\end{array}$ & 92206.00 & 29565.00 & 11420.00 & 11.27954 & 0.000000 & 303 & 190 \\
\hline $\begin{array}{l}\text { Medium } \\
\text { sized }\end{array}$ & 35680.50 & 13147.50 & 4891.500 & 8.783051 & 0.000000 & 184 & 128 \\
\hline
\end{tabular}

For the test data, it was not possible to use $X^{2}$ independence test statistics with one degree of freedom at the chosen significance level $\alpha=0.05$. Due to the failure to meet the good approximation conditions, Pearson's chi-test could not be used. For this reason, the data were tested using a Wilcoxon test (Mann Whitney $U$ test) at a chosen significance level $\alpha=0.05$, where $X=$ enterprises with TW and $Y=$ enterprises without TW, are tested hypotheses: $H_{0}=x_{0,50}-y_{0,50}$ $=0, \mathrm{H}_{\mathrm{A}}=\mathrm{x}_{0,50}>\mathrm{y}_{0,50}$. Where TW and non TW companies were compared, regardless of TW adoption duration.

As shown in the table above, the $\mathrm{p}$-value in the tested statistics is very close to 0 and therefore less than the chosen $\alpha=0.05$, and we can reject $\mathrm{HO}$ in favor of HA that enterprises with TW have a higher IT level than enterprises which do not use TW. Similarly, hypotheses were tested for groups of enterprises with or without a foreign owner and according to the size of the SME. In all the above-mentioned cases, a zero hypothesis with a p-value very close to zero was rejected and may be therefore concluded that the foreign owner and the size of the company do not have a significant effect on the established relationship between the use of TW and IT.

To imagine it better, there are graphs (Fig. 2) showing IT levels in relation to the use of TW in companies with a foreign owner in the left picture and without a foreign owner in the right picture. From the graphs, it is visible that TW companies with a foreign owner acquire IT levels between 0-6 and non-TW, maximally only 4. Also, the median value is at the IT level 3 for companies with TW versus the IT level 1 for SMEs without telework. This fact is also confirmed by the distribution of half the data between values 2-4 for TW companies and 0-2 for non-TW companies, as shown in the boxplot diagrams, where the upper quartile of TW companies starts at the maximum value of the non-TW companies.
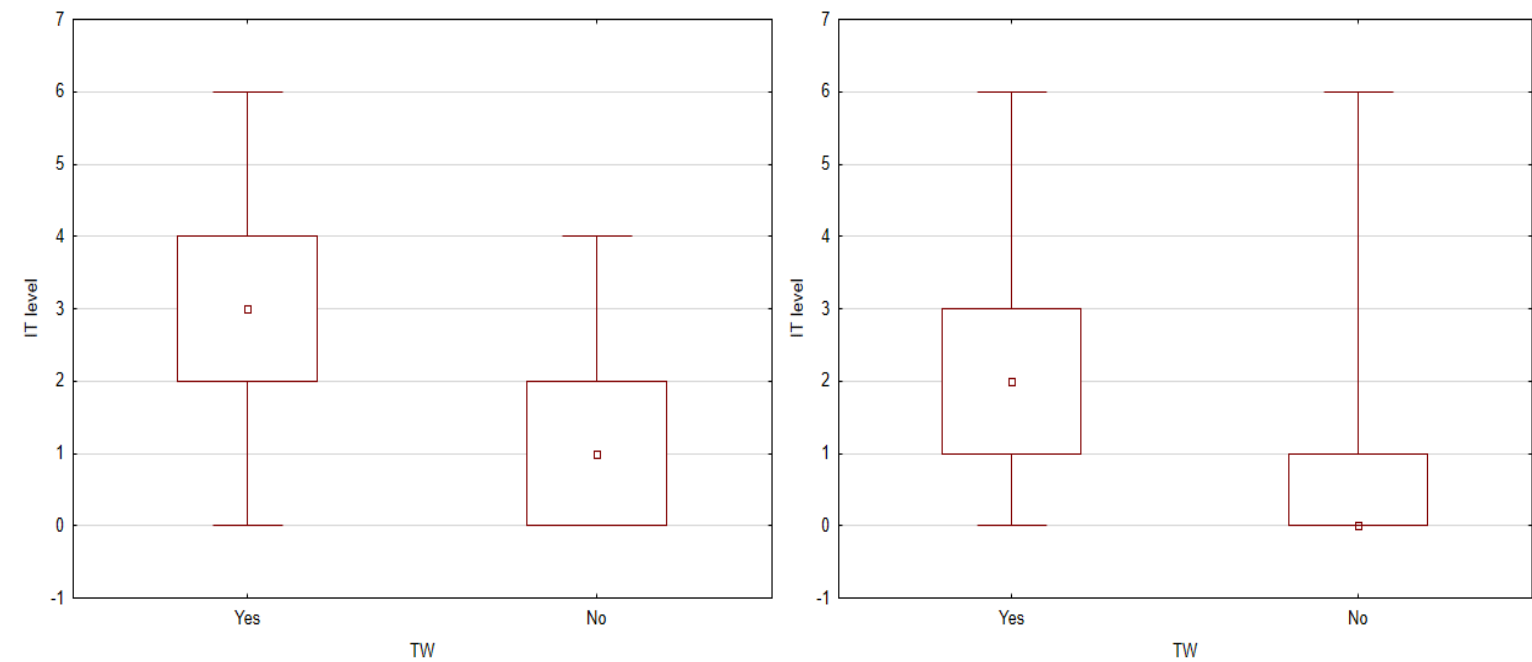

Fig 2. IT level in relation to TW for enterprises with or without a foreign owner. Source: processed by authors 
Comparable results are documented in the right boxplot where there are data from the companies without a foreign owner, where both groups have the same maxima and minima. It is interesting to note that there are enterprises with both TW and non-TW with the IT level 6. However, the SMEs without TW have a median of IT values at level 0 , compared to a median of level 2 for IT companies, where half of them is in the range of IT levels 1 and 2. The non-TW companies with no foreign ownership have scattered data in the upper quartile from 1 to 6 levels; therefore, a total of $75 \%$ of businesses in this category have an IT level of 0 or 1 .
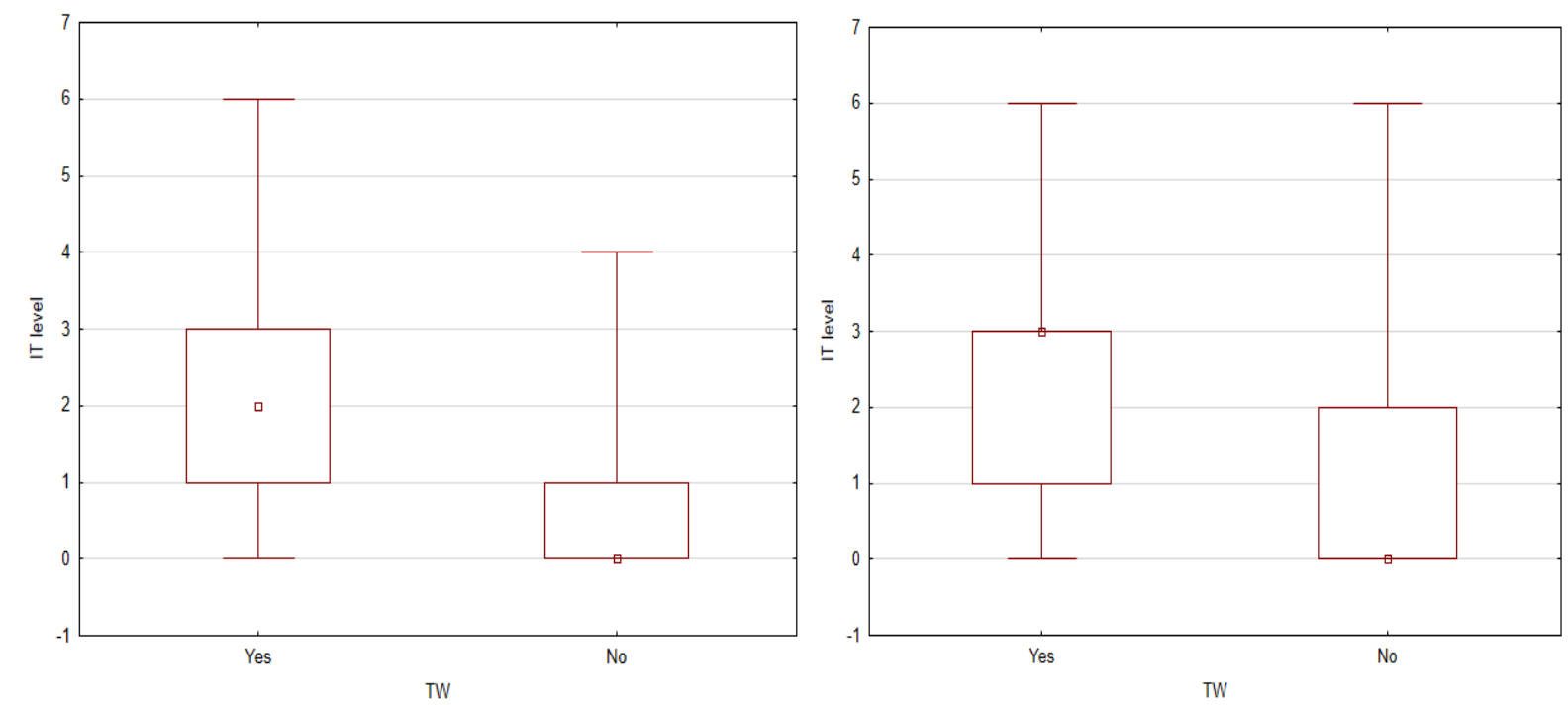

Fig 3. IT level in relation to TW for Small and Medium Enterprises. Source: created by authors

Regarding the significant differences between TW and non-TW companies in IT use, the data are supplemented by boxplots showing these differences in small businesses in the left boxplot and mid-sized businesses in the right boxplot. There is a difference between TW and non-TW companies in both groups of enterprises. For example, for Small enterprises, the range of IT level is only from 0 to 4 for non-TW companies, compared to the full range for SMEs that adopted TW. It is also thought-provoking that both Small and Medium enterprises have the same quartile distribution, where the lower quartile is between $0-1,50 \%$ of the values between 1-3 and the upper quartile is from 3 to 6 , but the median value is one value higher than for the Medium enterprises.

\subsection{TW and PJM}

Generally, 472 businesses use project management against 546 that do not use this management system. SMEs without project management represent $71 \%$ of the total number of non-TW SMEs. Similarly, $54 \%$ of non-project-managed SMEs do not have telework, which represents $29 \%$ of the largest group of companies of the whole. Most often, TW is used in SMEs with project management for $1-5$ years (43\%), 6-10 years (22\%) and for $11-20$ years (10\%). In the case of SMEs without project management, the use of TW is less, where 1-5 years represent $26 \%$, 610 years (12\%) and $11-20$ years (7\%). The two groups of companies that adopted TW and used TW for 11-20 years are the closest, with 54\% for PJM companies and $46 \%$ for non-PJM company, while in other time groups, there is a significantly higher representation of TW companies with PJM. 
Tab 4. Mann-Whitney U Test for TW Use in Project and Non-Project Management. Source: created by authors

\begin{tabular}{|l|c|c|c|c|c|c|c|}
\hline & Yes & No & U & $Z$ & $p$-value & $\begin{array}{c}\text { Number of } \\
\text { PJM } \\
\text { Yes }\end{array}$ & $\begin{array}{c}\text { Number of } \\
\text { PJM } \\
\text { No }\end{array}$ \\
\hline total & 276114.5 & 242556.5 & 93225.50 & 7.616440 & 0.000000 & 472 & 546 \\
\hline $\begin{array}{l}\text { Foreign } \\
\text { owner No }\end{array}$ & 159642.5 & 165578.5 & 57233.50 & 6.751950 & 0.000000 & 341 & 465 \\
\hline $\begin{array}{l}\text { Foreign } \\
\text { owner YES }\end{array}$ & 14897.50 & 7680.500 & 4359.500 & 2.178634 & 0.029360 & 131 & 81 \\
\hline Micro sized & 9131.000 & 13660.00 & 3790.000 & 3.090777 & 0.001997 & 73 & 140 \\
\hline $\begin{array}{l}\text { Small } \\
\text { Sized }\end{array}$ & 63198.00 & 58573.00 & 20623.00 & 5.952698 & 0.000000 & 218 & 275 \\
\hline $\begin{array}{l}\text { Medium } \\
\text { sized }\end{array}$ & 31397.50 & 17430.50 & 8784.500 & 3.904385 & 0.000094 & 181 & 131 \\
\hline
\end{tabular}

The data were tested using a Wilcoxon two-sample test (Mann-Whitney $U$ test) at the chosen significance level $\alpha=0.05$, where $X=$ companies with $P J M$ and $Y=$ companies without $P J M$ are tested hypotheses: $\mathrm{HO}=x 0.50-\mathrm{y} 0.50=0, \mathrm{HA}=\mathrm{x} 0.50>\mathrm{y} 0.50$. The zero hypothesis, as seen from the table above, was rejected in all cases and an alternative hypothesis was confirmed. Where $p$ values are in all cases smaller than the selected alpha. At the same time, in all cases there is the positive value for $Z$, which shows that the project-managed enterprises adopted telework a longer time ago, as shown in the graph below, where there is the data distribution from the point of view of the length of telework adoption and the project and non-project management. Therefore, it can be argued that project-managed SMEs use telework more often, in all categories, and the foreign owner or the size of the company do not influence as shown from the $p$-values listed in the table above.

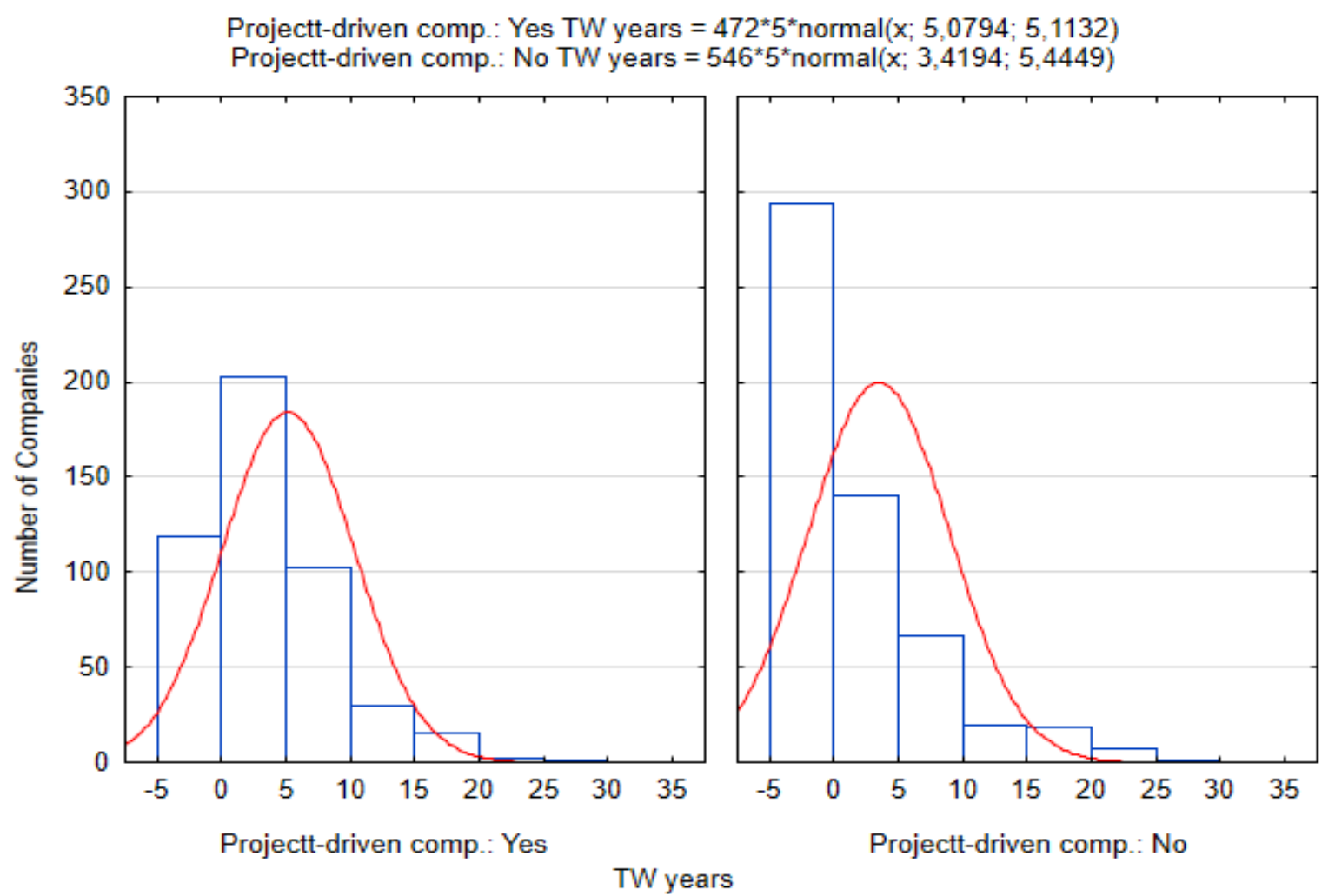

Fig 4. Distribution of TW data for companies with and without project management. Source: created by authors 


\section{Conclusion and Discussion}

In the Czech Republic, the basic legislative regulation of labor relations is enshrined in the Labor Code. However, telework is only marginally addressed in this legislative framework. On the other hand, when compared to The Telework Enhancement Act of 2010 signed into law by President Barack Obama on December 9 2010, which is a key factor in the ability to achieve greater flexibility in managing the telework, this is much more elaborate. The Telework Enhancement Act of 2010 require that the head of each executive agency establish and implement a policy under which employees shall be authorized to telework, and for other purposes. In this Act, there is basic definitions, executive agencies telework requirement, training and monitoring, policy and support, telework managing officer, reporting and others, but there is also a part about the telework research. It is said that the Director of the Office of Personnel Management shall research the utilization of telework by public and private sector entities, review the outcomes associated with an increase in telework, including the effects of telework on energy consumption, job creation and availability, urban transportation patterns, and the ability to anticipate the dispersal of work during periods of emergency and make any studies or reviews performed under this subsection available to the public.

What is interesting is that the average TW adoption time is seven years for SMEs. If we search the history, the world's economic crisis was probably the main trigger factor (Cihak, 2009; Dietrich, 2011) that hit the Czech economic system with a delay in 2009 (Prochniak, 2011; Kizys, 2011) and forced MSP to adopt economic measurements. On the other hand, modus and median are five years. At that time, the refreshment of the economic systems and the acceptation of the new manager trends such as the respect for the work and life balance had appeared, (which according to Steward, 2000; Hilbrecht, 2008; Salazar Solis, 2016) belong to the main TW advantages and at the same time, it classified the TW as the significant employee benefit as the interviews with the employees show (Baruch, 2000) and therefore, it is also a tool to keep the key employees because they tend to get used to it very quickly as the Swedish study from 2016 shown (Vilhelmson, 2016). The maximal limit mentioned by the inquired law firms were the use of TW for thirty years. This period is connected to the fact of Czech communistic economy in 1989 where there were no SMEs.

Surprisingly, there was no rejection of zero hypothesis on the independency of the firm size and the TW adoption as it was written in the article (Mayo, 2009). The authors assumed that larger companies, which are on the market for a longer time, have gone through more development phases, more sophisticated management systems, and thus will use TW for a longer time, has not been confirmed. One of the reasons may be the informal access in micro and small companies where employees often draw TWs based on oral and informal agreements with the owners of SMEs, while in more complex organizational structures associated with higher bureaucratic burden, it is impossible. Hála (2008) said that according to The Czech Statistical Office data for 2004, telework is most often used in micro-enterprises with 5-9 employees, and in the computer and related activities sector (almost $5 \%$ ). In terms of sectoral distribution, the next highest incidence of telework is in the post and telecommunications sector (4.6\%), followed by the manufacture of coke and petroleum products, chemicals, rubber and plastics sectors (3.8\%).

Some papers search the indicators showing which firms are likely to adopt the telework (Mayo, Pastor, Gomez-Mejia \& Cruz, 2009; Arvola, Tint, Kristjuhan, 2017). In Mayo Pastor, Gomez-Mejia \& Cruz (2009), the authors examined the reasons for the adoption of telework from the contingency perspective. Their empirical evidence showed that telecommuting correlated with small organizational size, a high proportion of international employees, and variable compensation. On the contrary to our research, the correlation between the size of the firm and the duration of the adoption of telework, has not been confirmed. Kraan, Blok (2018) said that common sectors in which telework occurs are the financial and commercial services, education and the public sector. Sub-sectors then are the ICT sector followed by the higher education sector.

The research has demonstrated the relationship between the foreign owner (not specified whether it is a minority or majority share) and the adoption of TW. The TW of the company with a foreign owner demonstrably makes more use of the sample. The Czech Republic has a total foreign share of 81 thousand. Among the main owners are Russians (16\%), Slovaks (12\%), 
Ukrainians (11\%) and Germans (9\%). If we look at the structure of these owners, however, we find that they are predominantly solo traders. Provided that only foreign legal entities are considered, the distribution would more than duplicate the connection of the Czech economy to the west. The main foreign legal entities are Germany (18\%), GB (15\%), Cyprus (13\%), the Netherlands (12\%), Austria (10\%) and Italy (10\%) (CRIF - Czech Credit Bureau, 2017). This fact supports the introduction of modern management systems and the introduction of more frequent TW, which was introduced by many German companies to obtain foreign managers into Czech companies. The adoption of TW should relieve the family so that the family members could spend the extended weekends together (Bosch, 2007). A very significant link, which was anticipated by the results of the Spanish (Mayo, 2009) and the Canadian study (Chalmers, 2008) has been confirmed between the IT levels and TW adoption. In the questionnaire, companies were asked which hardware and software devices supporting TW they use (Pulido, 2005) and based on the responses, SMEs were divided into 6 levels. Very few SMEs have reached the highest level of 6 , whereas $92 \%$ of SMEs have the level 4 . However, the dependence on IT and TW has been confirmed. In general, information technology is considered as one of the factors facilitating telework, whether it is a regional-occasional (Venkatesh, 2000) or continental-permanent (Fincato, 2015) distance. The data confirmed that $82 \%$ of companies with a zero IT level did not have TW, which is also supported by the fact that the majority of IT companies have adopted TW (Mehta, 2016).

Therefore, we are pleased to have confirmed this fact also for SMEs. In the future, we would like to explore deeper whether companies first introduced TW and thus developed IT, or vice versa, however, it is also necessary to see the risks in the form of loss of cognitive competences, as Taskin (2010) reports.

The last partial objective, the positive correlation between project management in SMEs and telework was demonstrated. Project management is often associated with the use of TW and thus allowing single individuals to work on multiple separate projects at once, thanks to the Internet and groupware. (Gallardo, 2013; Poulovassilis, 2015; Yap, 2017)

\section{Academic references}

[1] Abdel-Wahab, A. G. (2007). Employees' attitudes towards telecommuting. An empirical investigation in the Egyptian Governorate of Dakahlia. Behaviour and Information Technology 26(5), 367-375. DOI: 10.1080/01449290500535426.

[2] Aline, D. M., Steven, A. Y. P., Tammy, D. A., Paul, E. S., Laurent, M. L., Cary, L. C., Abarca, N., Brough, P., Vázquez Ferreiro, P., Fraile, G. M., Lu, L., Lu, C., Siu, O. L., O'Driscoll, MP., Suarez Simoni, A., Shima, S. \& Moreno-Velázquez, I. (2012). Flexible work arrangements availability and their relationship with work-to-family conflict, job satisfaction, and turnover intentions: A comparison of three country clusters. Applied Psychology 62(1), 1-29. DOI: 10.1111/j.1464-0597.2011.00453.x.

[3] Polydoropoulou, A. \& Tsirimpa, A. (2012). Women's Time Use with ICT and Physical Travel in Greek Urban and Rural Areas. SPOUDAI Journal of Economics and Business 62(1-2), 72-91.

[4] Armitage, R. (2000). An evaluation of secured by design housing within West Yorkshire [Research Report]. University of Huddersfield.

[5] Arvola, R., Tint, P. \& Kristjuhan, U. (2017). Employer attitude towards telework in real estate sector, In Economic Science For Rural Development (pp. 15-22). Jelgava: Latvian University of Life Sciences.

[6] Baltina, I. \& Vitola, A. (2014). Telework v Evropě a v Lotyšsku: moderní prístupy a budoucí perspektivy. Trendy ekonomiky a managementu 8(18), 21-32. 
[7] Baruch, Y. (2000). Teleworking: benefits and pitfalls as perceived by professionals and managers. New Technology Work and Employment 15(1), 34-49. DOI: 10.1111/1468005X.00063.

[8] Bělina, M., Drápal, L. et al. (2015). Zákoník práce. Komentár̆, 2nd ed. Praha: C. H. Beck.

[9] Boell, S. K., Cecez-Kecmanovic, D. \& Campbell, J. (2016). Telework paradoxes and practices: the importance of the nature of work. New Technology, Work and Employment 31(2), 114-131. DOI: 10.1111/ntwe.12063.

[10] Brenke, K. (2016). Home Offices: Plenty of Untapped Potential. DIW Economic Bulletin (8), 95-104.

[11] Budíková, M., Králová, M. \& Maroš, B. (2010). Průvodce základními statistickými metodami. Praha: Grada Publishing.

[12] Caulfield, B. (2015). Does it pay to work from home? Examining the factors influencing working from home in the Greater Dublin Area. Case Studies on Transport Policy 3(2), 206214. DOI: 10.1016/j.cstp.2015.04.004.

[13] Čihák, M. (2009). Financial crisis (Introduction). Czech Journal of Economics and Finance, 59(6), 502-506.

[14] de Graaff, T. \& Rietveld, P. (2007). Substitution between working at home and out-of-home: The role of ICT and commuting costs. Transportation Research Part A: Policy and Practice, 41(2), 142-160. DOI: 10.1016/j.tra.2006.02.005.

[15] Delery, J. E. \& Doty, D. H. (1996). Modes of theorizing in strategic human resource management: Tests of universalistic, contingency, and configurational performance predictions. Academy of Management Journal 39(4), 802-835. DOI: 10.2307/256713.

[16] Devore, J. L. (2015). Probability and Statistics for Engineering and the Sciences, $9^{\text {th }}$ ed. Boston, MA: Brooks Cole.

[17] Dietrich, D., Knedlik, T. \& Lindner, A. (2011). Central and Eastern European countries in the global financial crisis: a typical twin crisis? Post-Communist Economies 23(4), 415-432. DOI: 10.1080/14631377.2011.622561.

[18] Fincato, D. P. \& de Bitencourt, M. (2015). Cyber as Workplace: The Problem (or Solution?) of Transnational Teleworking. Quaestio luris 8(4), 2209-2235.

[19] Freeman, J., Shoesmith, E., Sweeney, D., Anderson, D. \& Williams, T. (2017). Statistics for Business and Economics, $4^{\text {th }}$ revised ed. Boston, MA: Cengage.

[20] Freund, R. J., Wilson, W. J. \& Mohr, D. L. (2010). Statistical methods (3 ${ }^{\text {rd }}$ ed). Amsterdam: Elsevier.

[21] Gallardo, J., Molina, A. I., Bravo, C. \& Redondo, M. A. (2013). A model-driven and taskoriented method for the development of collaborative systems. Journal of Network and Computer Applications 36(6), 1551-1565. DOI: 10.1016/j.jnca.2013.03.016.

[22] Gerhart, B., Wright, P. M., McMahan, G. C. \& Snell, S. A. (2000). Measurement error in research on human resources and firm performance: How much error is there and how does it influence effect size estimates? Personnel Psychology 53(4), 803-834. DOI: 10.1111/j.1744-6570.2000.tb02418.x.

[23] Haddad, H., Lyons, G. \& Chatterjee, K. (2009). An examination of determinants influencing the desire for and frequency of part-day and whole-day homeworking. Journal of Transport Geography 17(2), 124-133. DOI: 10.1016/j.jtrangeo.2008.11.008.

[24] Hála, J. (2008). Telework in the Czech Republic. Dublin: Eurofound.

[25] Handy, S. L. \& Mokhtarian, P. L. (1995). Planning for telecommuting: Measurement and policy issues. Journal of the American Planning Association 61(1), 99-111. DOI: $10.1080 / 01944369508975623$. 
[26] Helminen, V. \& Ristimäki, M. (2007). Relationships between commuting distance, frequency and telework in Finland. Journal of Transport Geography 15, 331-342. DOI: 10.1016/j.jtrangeo.2006.12.004.

[27] Hilbrecht, M., Shaw, S. M., Johnson, L. C. \& Andrey, J. (2008). „I'm home for the kids": Contradictory implications for work-life balance of teleworking mothers. Gender Work and Organization 15(5), 454-476. DOI: 10.1111/j.1468-0432.2008.00413.x.

[28] Huselid, M. A. (1995). The Impact of Human Resource Management Practices on Turnover, Productivity, and Corporate Financial Performance. Academy of Management Journal, 38, 635-672. DOI: 10.2307/256741.

[29] Chalmers, L. (2008). Using IT in work at home: taking a closer look at IT use in home-located production. New Technology Work and Employment 23(1-2), 77-94. DOI: 10.1111/j.1468005X.2008.00204.X.

[30] Jiang, K., Lepak, D. P., Hu, J. \& Baer, J. C. (2012). How does human resource management influence organizational outcomes? A meta-analytic investigation of mediating mechanisms. Academy of Management Journal 55(6), 1264-1294. DOI: 10.5465/amj.2011.0088.

[31] Kizys, R. \& Pierdzioch, C. (2011). The financial crisis and the stock markets of the CEE countries. Czech Journal of Economics and Finance, 61(2), 153-172.

[32] Křižková, A. (2007). Nepřiliš harmonická realita. Rodičovské kombinace práce a péče v mezích genderové struktury současné české společnosti. Gender, rovné príležitosti, výzkum 8(2), 60-67.

[33] Křížková, A. \& Vohlídalová, M. (2009). Rodiče na trhu práce: mezi prací a péčí/Parents in the Labor Market: Between Work and Care. Czech Sociological Review 45(1), 31-60.

[34] Kurland, N. B. \& Bailey, D. E. (1999). The advantages and challenges of working here, there anywhere, and anytime. Organizational Dynamics 28(2), 53-68. DOI: 10.1016/S00902616(00)80016-9.

[35] Kyzlinková, R. \& Svobodová, K. (2007). Práce z domova a její zásah do rodinného života. Fórum sociální politiky 1(1), 11-17.

[36] Mannering, J. S. \& Mokhtarian, P. L. (1995). Modeling the choice of telecommuting frequency in California: An exploratory analysis. Technological Forecasting and Social Change 49(1), 49-73. DOI: 10.1016/0040-1625(95)00005-U.

[37] Martin, B. H. \& MacDonnell, R. (2012). Is telework effective for organizations? A metaanalysis of empirical research on perceptions of telework and organizational outcomes. Management Research Review 35(7), 602-616. DOI: 10.1108/01409171211238820.

[38] Maříková, H. (2008). Mateřství, rodina a práce z pohledu matek malých dětí. Gender, rovné přiležitosti, výzkum 9(2), 45-55.

[39] Mayo, M., Pastor, J. C., Gomez-Mejia, L. \& Cruz, C. (2009). Why some firms adopt telecommuting while others do not: A contingency perspective. Human Resource Management 48(6), 917-939. DOI: 10.1002/hrm.20322.

[40] Mehta, B. S. (2016). A decent work framework: women in the ICT sector in India. Information Development 32(5), 1718-1729. DOI: 10.1177/0266666915623249.

[41] Meloun, M., Militký, J. \& Hill, M. (2012). Statistická analýza vícerozměrných dat v př́kladech, $2^{\text {nd }}$ ed. Praha: Academia.

[42] Morgan, R. E. (2004). Teleworking: an assessment of the benefits and challenges. European Business Review 16(4), 344-357. DOI: 10.1108/09555340410699613.

[43] Muhammad, S., Ottens, H. F. L., Ettema, D. \& de Jong, T. (2007). Telecommuting and residential locational preferences: a case study of the Netherlands. Journal of Housing and the Built Environment, 22(4), 339-358. DOI: 10.1007/s10901-007-9088-3. 
[44] Muhammad, S., Ottens, H. F. L. \& Jong, T. de. (2008). Modelling the impact of telecommuting on future urbanisation in the Netherlands. Tijdschrift Voor Economische En Sociale Geografie 99(2), 160-177. DOI: 10.1111/j.1467-9663.2008.00452.x.

[45] Peters, P. \& van der Lippe, T. (2007). The time-pressure reducing potential of telehomeworking: the Dutch case. International Journal of Human Resource Management 18(3), 430-447. DOI: 10.1080/09585190601167730.

[46] Peters, P., den Dulk, L. \& de Ruijter, J. (2010). May I work from home? Views of the employment relationship reflected in line managers' telework attitudes in six financialsector organizations. Equality, Diversity and Inclusion 29(5), 517-531. DOI: 10.1108/02610151011052799.

[47] Potter, E. E. (2003). Telecommuting: The future of work, corporate culture, and American society. Journal of Labor Research, 24(1), 73-84. DOI: 10.1007/s12122-003-1030-1.

[48] Poulovassilis, A., Xhafa, F. \& O'Hagan, T. (2015). Event-Based Awareness Services for P2P Groupware Systems. Informatica 26(1), 135-157. DOI: 10.15388/Informatica.2015.42.

[49] Prochniak, M. (2011). Determinants of economic growth in Central and Eastern Europe: the global crisis perspective. Post-Communist Economies 23(4), 449-468. DOI: $10.1080 / 14631377.2011 .622566$.

[50] Pulido, J. C. R. \& Lopez, F. J. M. (2005). Teleworking in the information sector in Spain. International Journal of Information Management 25(3), 229-239. DOI: 10.1016/j.ijinfomgt.2005.02.002.

[51] Ravi, S. G. \& David, A. H. (2007). The Good, the Bad, and the Unknown About Telecommuting: Meta-Analysis of Psychological Mediators and Individual Consequences. Journal of Applied Psychology 92(6), 1524-1541. DOI: 10.1037/0021-9010.92.6.1524.

[52] Redman, T., Snape, E. \& Ashurst, C. (2009). Location, Location, Location: Does Place of Work Really Matter? British Journal of Management 20(1), 171-181. DOI: 10.1111/j.14678551.2008.00640.x.

[53] Salazar Solis, M. (2016). Telework: conditions that have a positive and negative impact on the work-family conflict. Academia-Revista Latinoamericana De Administracion, 29(4), 435449. DOI: 10.1108/ARLA-10-2015-0289.

[54] Seung-Nam, K. (2016). Two traditional questions on the relationships between telecommuting, job and residential location, and household travel: revisited using a path analysis. The Annals of Regional Science, 56(2), 537-563. DOI: 10.1007/s00168-016-07558.

[55] Spellman, F. R. \& Whiting, N. E. (2014). Handbook of mathematics and statistics for the environment. Boca Raton: CRC Press.

[56] Steil, A. V. \& Barcia, R. M. (2001). An Assessment Model to Analyze Organizational Readiness to Implement Telework Arrangements. In Camarinha-Matos, L. M., Afsarmanesh, H., Rabelo, R. J., eds., E-Business and Virtual Enterprises (pp. 455-464). Boston, MA: Springer. DOI: 10.1007/978-0-387-35399-9_44.

[57] Steward, B. (2000). Changing times - The meaning, measurement and use of time in teleworking. Time \& Society 9(1), 57-74. DOI: 10.1177/0961463X00009001004.

[58] Taskin, L. \& Bridoux, F. (2010). Telework: a challenge to knowledge transfer in organizations. International Journal of Human Resource Management 21(13), 2503-2520. DOI: 10.1080/09585192.2010.516600.

[59] Tayyaran, M. R. \& Khan, A. M. (2007). Telecommuting and residential location decisions: combined stated and revealed preferences model. Canadian Journal of Civil Engineering 34(10), 1324-1333. DOI: 10.1139/L07-052. 
[60] Temelová, J., Novák, J., Pospíšilová, L. \& Dvořáková, N. (2011). Každodenní život, denní mobilita a adaptační strategie obyvatel v periferních lokalitách. Sociologický časopis/Czech Sociological Review 47(4), 831-858.

[61] Venkatesh, V. \& Speier, C. (2000). Creating an effective training environment for enhancing telework. International Journal of Human-Computer Studies 52(6), 991-1005. DOI: 10.1006/ijhc.1999.0367.

[62] Verbeke, A., Schulz, R., Greidanus, N. \& Hambley, L. (2008). Growing the Virtual Workplace: The Integrative Value Proposition for Telework, Cheltenham, UK \& Northampton, MA: Edward Elgar. DOI: 10.4337/9781848440241.00001.

[63] Vilhelmson, B. \& Thulin, E. (2016). Who and where are the flexible workers? Exploring the current diffusion of telework in Sweden. New Technology, Work and Employment 31(1), 77-96. DOI: 10.1111/ntwe.12060.

[64] Walker, I. (2010). Research Methods and Statistics. London: Palgrave Macmillan.

[65] Wright, P. M. \& McMahan, G. C. (1992). Theoretical perspectives for strategic human resource management. Journal of Management 18(2), 295-320. DOI: $10.1177 / 014920639201800205$.

[66] Wright, P. M. \& Mcmahan, G. C. (2011). Exploring human capital: Putting "human" back into strategic human resource management. Human Resource Management Journal 21 (2), 93104. DOI: $10.1111 /$ j.1748-8583.2010.00165.x.

[67] Yap, J. B. H. \& Lock, A. (2017). Analysing the benefits, techniques, tools and challenges of knowledge management practices in the Malaysian construction SMEs. Journal of Engineering Design and Technology 15(6), 803-825. DOI: 10.1108/JEDT-07-2017-0067.

\section{Other sources}

[68] Bosch, internal dokuments (work and family) (2007).

[69] CRIF - Czech Credit Bureau, (2017). Struktura zahraničních vlastníků v ČR. Praha: CRIF press.

[70] Eurofound and the International Labour Office (2017). Working anytime, anywhere: The effects on the world of work. Publications Office of European Union, Luxembourgh, and the International Labour Office, Geneva.

[71] Implementation of the European Framework Agreement on Telework (2006). Report by the European Social Partners. Retrieved from: https://resourcecentre.etuc.org/ linked_files/documents/Framework \%20agreement \%20on \%20telework \%20EN.pdf Access: 8.01.2017.

[72] Kraan, K. \& Blok, M. (2018). Telework. The Netherlands. Retrieved from: https://oshwiki.eu/wiki/Telework.

[73] The Telework Enhancement Act of 2010. One Hundred Eleventh Congress of the United States of America. Retriewed from: https://www.govinfo.gov/content/pkg/BILLS111hr1722enr/pdf/BILLS-111hr1722enr.pdf. 